\title{
Study of Antiepileptic Effect of Pentazocine And Combination Of Pentazocine With Phenytoin In Experimentally Induced Convulsions In Albino Rats
}

\author{
Dr .Maddala rajitha ${ }^{1}$, J.Balu $^{2}$, A.viswashanthi ${ }^{3}$ \\ ${ }^{1,2,3}$ (Department Of Pharmacology, Nimra Institute Of Medical Sciences, Vijayawada/ Dr.NTR,UHS, Andhra \\ Pradesh, India)
}

\begin{abstract}
:
Aims\& objectives: The present study was designed to compare the anti convulsant effect of pentazocine with standard phenytoin sodium and also combination of different doses of pentazocine with different doses of phenytoin in experimentally induced albino rats.

Materials\& methods: 30 albino rats of either sex weighing 150 to 200 gms were selected and randomly divided in to 5 equal groups with 6 rats in each group, maximal electro shock seizures(MES) were induced in albino rats via trans auricular electrodes ( $150 \mathrm{~mA}, 0.2$ seconds) each rat was pretreated at 30 minutes before MES test with drugs intraperitoneally.

Statistical Analysis: Descriptive data that include Mean, Standard Deviation, and standard error value were found for each group and used for analysis. One way ANOVA was used for multiple group comparison. $P$ value of 0.05 or less was considered for statistical significant.

Resuts: intraperitoneal administration of pentazocine resulted in reduction of different phases of convulsions during MES method. Different dose combination of pentazocine \&phenytoin also reduced the duration of different phases of convulsions

Conclusion: the anticonvulsant effect of pentazocine alone is superior to the effect of combination of pentazocine and phenytoin in the seizure models. Pentazocine alone was comparable to that of the standard drug in electrically induced seizures.
\end{abstract}

Keywords: Albinorats, intraperitoneal route, maximal electro shock method, pentazocine, phenytoin

\section{Introduction}

The epilepsies are common and frequently devastating disorders ${ }^{[1]}$.The second most common disorder of the central nervous system after stroke ${ }^{[2]}$. Epileptic seizures often cause transient impairment of consciousness leaving the individual at risk of bodily harm and often interfering employment ${ }^{[3]}$. Starting from role of bromides on Epilepsy to recent newer anti Epileptics. There is a still need for an ideal anti epileptic agent with properties like broad spectrum of activity, rapid onset of action, least side effects, good oral bioavailability, and low cost. In contrast to opioids activating seizures many studies demonstrated that opioid peptides with pharmacological electivity for mu, delta, Kappa, binding sites are anti convulsants ${ }^{[4-7] .}$ It is interesting to note that mu, delta, kappa, opioids selectively hyperpolarize neurons throughout the $\mathrm{CNS}^{[8-}$

${ }^{10]}$,Therefore it seems possible that opioid peptides may indeed form as endogenous anticonvulsant in the CNS modulating the underlying mechanisms of seizures arrestand refractoriness which are critical to the suppression of convulsions ${ }^{[11-19]}$. Subcutaneous or intra cerebro ventricular administration of $U_{50,488}$ a highly selective kappa opioid agonist, resulted in a dose and time dependent anticonvulsant action in rats ${ }^{[20]}$. Pentazocine is known to act as a agonist at kappa opioid receptors and a weak antagonist or a partial agonist at mu receptors ${ }^{[21,22]}$ .According to the studies pentazocine increased the anti convulsant effect of phenytoin ${ }^{[23]}$. By keeping in this view . The present study was undertaken to evaluate the anti convulsant activity of pentazocine and the combination of different doses of pentazocine and phenytoin in experimentally induced seizures in albino rats.

\section{Methodology}

Albino rats of either sex of average weight $(150-200 \mathrm{~g})$ which were obtained from National institute of nutrition, Hyderabad, and maintained at the central animal house A.S.R.A.M. Medical College, ELURU used for the study. Institutional animal ethical committee permission was taken for the study. 30 albino rats of either sex weighing 150-200g were selected and randomly divided into 5 equal groups containing 6 in each group.All the test animals were allowed food and water ad libitum both being withdrawn just prior to experimentation. All the test animals were subjected to further experiment of this study after 24hrs (to avoid any possible "Kindling" effect). All the preparations were administered intraperitoneal route. Animals were used to induce convulsions by maximal electroshock method. The above test animals were subjected to electroshock of $150 \mathrm{~mA}$ intensity for 
0.2 seconds, through auricular electrodes, (covered in cotton wool and saline moistened). A majority of rats showed tonic flexion and extension of fore and hind limbs, clonus, stupor followed by post ictal depression and recovery. Only those rats showing the convulsive responses were used for experiment.

2.1 Inclusion Criteria:

o Animals weighing 150-200g.

o Healthy with normal behavior and activity.

2.2 Exclusion Criteria:

o Animals weighing more than $200 \mathrm{~g}$ and less than $150 \mathrm{~g}$.

o Pregnant female and those which have delivered once.

\subsection{Groups}

Group - I animals (Control group )received $0.5 \mathrm{ml} / \mathrm{kg}$ body weight distilled water.

Group - II animals (Standard group) Six albino rats received $135 \mathrm{mg} / \mathrm{kg}$ of phenytoinsodium.

Group - III animals (Test group I ; T1) Six albino rats received pentazocine $30 \mathrm{mg} / \mathrm{kg}$

Group - IV animals (Test groupII ; T2) Six albino rats received $15 \mathrm{mg} / \mathrm{kg}$ of pentazocine andinj phenytoin $10 \mathrm{mg} / \mathrm{kg}$.

Group - V animals (Test group- III; T3)six albino rats received 30mg/kg of pentazocine and $20 \mathrm{mg} / \mathrm{kg}$ of phenytoin.

2.4 The Parameters studied are:

2.4.1..Duration of convulsions

2.4.2 Hind limb tonic extension-HLE in seconds

2.4.3.duration of recovery in seconds

2.5.Statistical Analysis: Descriptive data that include Mean, Standard Deviation, and standard error value were found for each group and used for analysis. One way ANOVA was used for multiple group comparison. P value of 0.05 or less was considered as significant

\section{Table-1}

\section{Results}

Comparison of duration of convulsions (in seconds) by MES method among 5 groups

$>$ Group I control group given distilled water I.P

$>$ Group II standard group given phenytoin sodium $135 \mathrm{mg} / \mathrm{kg}$ I.P

$>$ Group III test I given Inj pentazocine $30 \mathrm{mg} / \mathrm{kg}$ I.P

\begin{tabular}{|l|l|l|l|l|}
\hline Group & N(size of sample) & Mean(seconds) & $\begin{array}{l}\text { Standard } \\
\text { deviation }\end{array}$ & Standard error \\
\hline Group-I & 6 & 70.3 & 3.87 & 1.61 \\
\hline Group-II & 6 & 21.3 & 3.93 & 1.64 \\
\hline Group-III & 6 & 26.5 & 7.5 & 3.12 \\
\hline Group IV & 6 & 46.3 & 6.9 & 2.88 \\
\hline Group V & 6 & 50 & 7.07 & 2.94 \\
\hline
\end{tabular}

- Group IV test 2 given Inj pentazocine $15 \mathrm{mg} / \mathrm{kg}+$ Inj phenytoin $10 \mathrm{mg} / \mathrm{kg} \mathrm{I.P}$

$>$ Group V test 3 given Inj Pentazocine $30 \mathrm{mg} / \mathrm{kg}+$ Inj phenytoin $20 \mathrm{mg} / \mathrm{kg}$ I.P

Table-2 Comparison of duration of THLE by MES method (in seconds) among 5 groups

\begin{tabular}{|l|l|l|l|l|}
\hline Group & N(size of sample) & Mean(seconds) & Standard deviation & $\begin{array}{l}\text { Standard } \\
\text { error }\end{array}$ \\
\hline Group-I & 6 & 11.75 & 2.07 & 0.8 \\
\hline Group-II & 6 & 0 & 0 & 0 \\
\hline Group-III & 6 & 0 & 0 & 0 \\
\hline Group IV & 6 & 3.3 & 1.09 & 0.45 \\
\hline Group V & 6 & 3.4 & 0.54 & 0.22 \\
\hline
\end{tabular}

$>$ Group I control group given distilled water I.P

$>$ Group II standard group given phenytoin sodium $135 \mathrm{mg} / \mathrm{kg}$ I.P

$>$ Group III test I given Inj pentazocine $30 \mathrm{mg} / \mathrm{kg}$ I.P

$>$ Group IV test 2 given Inj pentazocine $15 \mathrm{mg} / \mathrm{kg}+$ Inj phenytoin $10 \mathrm{mg} / \mathrm{kg}$ I.P

$>$ Group V test 3 given Inj Pentazocine 30mg/kg + Inj phenytoin 20mg/kg I.P 
Study of Antiepileptic Effect of Pentazosine And Combination Of Pentazosine...

Table-3 Comparison of duration of Recovery phase by MES method among 5 groups

\begin{tabular}{|l|l|l|l|l|}
\hline Group & N(size of sample) & $\begin{array}{l}\text { Mean } \\
\text { (seconds) }\end{array}$ & $\begin{array}{l}\text { Standard } \\
\text { deviation }\end{array}$ & Standard error \\
\hline Group-I & 6 & 50.6 & 3.2 & 1.35 \\
\hline Group-II & 6 & 13 & 2.36 & 0.98 \\
\hline Group-III & 6 & 24.3 & 5.74 & 2.39 \\
\hline Group IV & 6 & 45.8 & 10.8 & 4.52 \\
\hline Group V & 6 & 35.1 & 5.91 & 2.46 \\
\hline
\end{tabular}

$>$ Group I control group given distilled water I.P

$>$ Group II standard group given phenytoin sodium $135 \mathrm{mg} / \mathrm{kg}$ I.P

$>$ Group III test I given Inj pentazocine $30 \mathrm{mg} / \mathrm{kg}$ I.P

$>$ Group IV test 2 given Inj pentazocine $15 \mathrm{mg} / \mathrm{kg}+$ Inj phenytoin $10 \mathrm{mg} / \mathrm{kg}$ I.P

$>$ Group V test 3 given Inj Pentazocine 30mg/ $\mathrm{kg}+$ Inj phenytoin 20mg/kg I.P

\section{Discussion}

Pentazocine is weak competitive antagonist at the mu receptor and agonist at the kappa receptor in higher doses weak sigma agonist.Therefore according to the studies mentioned above the probable anticonvulsant action of pentazocine is due to kappa and sigma receptors ${ }^{[24-29]}$.

At the molecular level the mu, delta kappa receptors largely couple through pertusis toxin sensitive $G$ protein. Upon receptor activation $G$ protein coupling results in a large number of intracellular events including ${ }^{\text {[30,31] }}$

a) Inhibition of adenylcyclase leading to decrease in $\mathrm{C}_{\mathrm{Amp}}$ with consequent decrease in cell excitability.

b) Activation of potassium channels and subsequent increase in potassium conductance to produce hyperpolarization of neurons and a decrease in their excitability.

c) Inhibition of calcium conductance by suppressing voltage gated $\mathrm{N}$ type of calcium channels.

Several studies reported that the sigma receptor modulate the neuronal firing and the neurotransmitter release.Nuwayhid and werling recently demonstrated that sigma receptor agonists regulate the NMDA induced dopamine release from rat striated slices via protein kinase c.Debonnel and colleagues demonstrated that sigma ligands modulate glutamatergic and seratonergic neurons.Several studies demonstrated both type1 and type2 sigma receptors regulate calcium efflux from the endoplasmic reticulum In this present study Pentazocine alone and combination of pentazocine with phenytoin evaluated for anticonvulsant activity by maximal electroshock method induced seizures The test drugs are compared with both the control (distilled water) and the standard (phenytoin sodium). Analysis of the results of group - III that received $30 \mathrm{mg} / \mathrm{kg}$ body weight of pentazocine when compared to control group, the mean duration of various parameters were reduced like duration of convulsions (table-1), hind limb extension(table-2), duration of recovery from postictal depression(table-3) was found significant. And when compared with the standard phenytoin sodium, the mean duration of various parameters like duration of convulsions ( $p$ value- 0.18 ), tonic hind limb extension found to be non significant . The recovery phase ( $p$ value -0.0029 ) little bit significant. This implies that pentazocine in a dose of $30 \mathrm{mg} / \mathrm{kg}$ body weight have significant anticonvulsant activity. Therefore the result of the present study demonstrated that Pentazocine elicited and effective protection against MES seizures in Albino rats .

Analysis of the results of group - IV that received combination of inj pentazocine $15 \mathrm{mg} / \mathrm{kg}$ body weight and phenytoin sodium $10 \mathrm{mg} / \mathrm{kg}$ when compared to control group the various parameters of like duration of convulsions(table1), total hind limb extension(table2), duration of post ictal depression recovery(table 3 ), is significant. when compared with standard phenytoin sodium mean duration of various parameters like duration of convulsions, total hind limb extension, recovery phase are significant. When compared with group - V mean duration of various parameters found to be non significant. Analysis of the results of group - V that received combination of inj pentazocine $30 \mathrm{mg} / \mathrm{kg}$ body weight and phenytoin $20 \mathrm{mg} / \mathrm{kg}$ when compared to control group the mean duration of various parameters like duration of convulsions, total hind limb extension, duration of post ictal depression recovery is significant. when compared with standard phenytoin sodium mean duration of various parameters like duration of convulsions, total hind limb extension, recovery phase are significant. When compared with group - IV mean duration of various parameters found to be non significant. As expected Phenytoin provided complete protection against MES while Pentazocine when co administered with sub anticonvulsant dose of Phenytoin and even combination of anti convulsant doses combination of both drugs was not provided significant protection. This observation not agrees with an earlier report, that in a study by Hans Hassofrey it was suggested that prior administration of morphine like analgesics like Fentanyl, Pentazocine increased the Anti Electroshock effect of Phenytoin and Phenobarbitol.

The reason for the contrary results of the study from the previous studies may not be properly known. It may be due to species variation or any other Pharmacokinetic, Pharmacodynamic mechanisms may be involved which need to be evaluated by further studies 


\section{Conclusion}

The present study demonstrated that Pentazocine elicited an effective protection against MES seizures in Albino rats This implies that pentazocine in a dose of $30 \mathrm{mg} / \mathrm{kg}$ body weight have significant anticonvulsant activity. Pentazocine when co administered with sub anticonvulsant dose of Phenytoin and even combination of anti convulsant doses of both drugs was not provided significant protection. Therefore pentazocine not increasing the anticonvulsant effect of phenytoin but decreasing. Further studies are needed to know the interactions between both drugs.

\section{References}

[1]. Bruce chabner, Bjorn Knollman,Goodman \&Gilmans The pharmacological basis of therapeutics $12^{\text {th }}$ edition P $583-601$

[2]. Leanardi M.uston TB. The global burden of Epilepsy. Epilepsia 2002;43(supp 1.6) :21-5

[3]. J.M.K Murthy seizure disorders. In API textbook of medicine $8^{\text {th }}$ edition vol 12: Association of physicians of india :2008: $\mathrm{p} 11$

[4]. Bohaus,D.W:Rigsbee,L.C:mcNaroma, J.O Intranigraldynorphin 1-13 supresses kindledseizures by a naloxone insensitive mechanism brain res ,405:358-363:1987

[5]. Garant D.S:Gale K.Infusion of opiate into substantia nigra protects against maximal electroshock seizures in rats J.pharmacol Exp Ther.234:45-48:1985.

[6]. Tortella .F.C;Robles,L:Holaday.J.W cowan,A selective role for delta receptors in regulation of opioid induced changes in seizure threshold life sci 33:603-606:1983

[7]. Vonvioghtlander.P.F:Hall .D:Camacho.O:Lewis.R.A:Trienzenberg.H.j.U.54494A:A unique anti convulsant related to kappa opioid agonists J.Pharmacol.Exp.ther.243:542-547:1988.

[8]. Dickeson,A.H:Sullivan,A:Feeney,C:Fourine-Zaluski.M.C:Roques,B.P Evidence that endogenous enkephalins produce delta -opiate receptor mediated neuronal inhibitions in rat dorsal horn.neurosic.lett 72:179-182:1986.

[9]. Duggan,A.W:North,R.A Electrophysiology of opioids pharmacol.Rev 35:219-281:1984.

[10]. Werz.M.A:mac Donald,R.1 Dynorphin \& neoendorphin peptides decreases dorsal root ganglion neuron calcium dependant action potential duration J.Pharmacol.Exp.ther 234:49-56-1985.

[11]. Hokfelt,T:Elde,R:Johnson ,O:jerenius, L:stein .The distribution of enkephalin -immuno reactive cell bodies in rat central nervous system neuroscu.Lett.5:25-311977.

[12]. Mc ginty,J.f :kanamatsu T:obie ,J.Dyer,R.S:Mitchell .C.1:Hong .J.S Amygdaloid kindling increases enkephalin like immune reactivity but decreases dynorphin-alike immuno reactivity in rat hippo campus .neuro sci.lett.71;31-36:1986.

[13]. SAR, M;sumpf.W.E;miller.R.J:Chang.K.J;Cuatracasas, P.immunohisto chemical localization of enkephalin in the rat brain and spinalcord.J.comp.neurol .44:501-512;1986.

[14]. Siggins.G.S;Henriksen,S.J;chaukin,C;groul,D.opioid peptides and epilepto genesis in the limbic system;cellular mechanism.Adv, neurol 44;501-512 1986

[15]. Wmsley,J;young W;kuhar,M.immuno histo chemical localization of enkephalin in rat fore brain. Brain res 190:153-174;1980.

[16]. cardecott-hazard,s:Engel,J.limbic postictal events:Anatomical substrates and opioid receptor involvement.prog.neuropsychopharmacol.biol,psychiatry 11:389-418:1987.

[17]. Holoday J.W.Tottella,F.C:Long J.B :Belrnky, G.L:Hitzemann,R.J Electroconvulsive shock activates endogenous opioid systems :behavioural and biochemical correlates Ann.Ny Acad.sci467:249-255 1987.

[18]. Tortella.F.C.opioid peptides,possible physiological role as endogenous anticonvulsants in :Ferrendelli:J:Collins ,R:Johnson E.edes neurobiology of amino acids peptides and trophic factors Boston:Kluwer Academic:1988:163-179

[19]. Mw adler; Ch lin; shkeinath; sbraverman; EBGeller, Jpharmacol xpther,1976,198, 665.70

[20]. FC Tortella, L Robles; JW Holaday.J pharmacol Epther,1986,237,49-53.

[21]. RANG AND DALE'S pharmacology $7^{\text {th }}$ edition pg.510-520.

[22]. Bruce Chabner .Bjorn Knollman Goodman \&Gilman's the pharmacological basis of Therapeutics $12^{\text {th }}$ edition p.g no $481-521$.

[23]. Hans-Hassofrey.interactions between morphine like Analgesics \& Anticonvulsants drug phe: $25^{\text {th }}$ march 2009

[24]. manocha Anshu, kksharma , Pk mediratta, The anticonvulsant effect of pentazocine against maximal electroshock seizures in mice. In J.J.P 1997 volume 29 Issue 3 page 194-197

[25]. http.//www.jjp-onlilne.com/article.asp;jssn=0253-7613 year 1997

[26]. khanna N.khosla R.kohlij .Opioid receptor mediated anticonvulsant effect of pentazocine Indian med sci.1998 jan;52(1):1-7

[27]. manocha et al Tramadol, a centrally acting opioid ; anticonvulsant effect aganist maximal electroshock seizure in mice Indian J.physiol pharmacol 1998.Jul;42(3):407-11

[28]. manocha et al possible mechanism involved in the anticonvulsant action of butorphanol in mice pharmacol biochem behmau .2003jan;74(2):343-50.

[29]. Manocha A, et al on the mechanism of anticonvulsant effect of tramadol in micro pharmacol Biochem Behau.2005 sep;82(1):7481.

[30]. Praveen panchanksherimath et al; study on the anticonvulsant activity of pentazocine in albino rats J.chem.pharm.Res 2011,3(5);468-472

[31]. RANG AND DALE'S pharmacology $7^{\text {th }}$ edition pg.510-520.

[32]. Bruce Chabner .Bjorn Knollman Goodman \&Gilman's the pharmacological basis of Therapeutics $12^{\text {th }}$ edition p.g no $481-521$.

[33]. E.J Cobos, J.M Entrena, \& E Deipozo Pharmacology and therapeutic potential of Sigma1 Receptor Ligands current neuro pharmacology,2008,6,344-366.

[34]. Huanmin Gao, Chao Wang role of intra hippocampal sigma receptor in inhibiting seizures by electroacupuncture in rats vol 22:issue.1:pages 19-24. 